\title{
Natural Products in Drug Discovery: Antibacterial and Antifungal Activity of Essential Oil of Compound Isolated from Senecio royleanus
}

\author{
Chandra Mohan Singh Bisht ${ }^{1}$, S.M. Shakeel Iqubal ${ }^{2 *}$ (D) Aejaz A. Khan ${ }^{2}$, \\ Tasneem Mohammed ${ }^{2}$ (D) Areej Dawoud², Mohammed Gamal ${ }^{3,4}(D)$, S.K. Singh \\ and Basim H. Asghar 6 (D)
}

\begin{abstract}
${ }^{1}$ Department of Applied Science, IIMT College of Engineering, Greater Noida - 201 301, India. ${ }^{2}$ Department of General Science (Chemistry), Ibn Sina National College, Jeddah, Saudi Arabia. ${ }^{3}$ Pharmaceutical Chemistry Department, Faculty of Pharmacy, Jouf University, Skaka 2014, Kingdom of Saudi Arabia. ${ }^{4}$ Pharmaceutical Analytical Chemistry Department, Faculty of Pharmacy, Beni-Suef University, AlshaheedShehata Ahmed Hegazy St., 62574 Beni-Suef, Egypt. ${ }^{5}$ Department of Chemistry, GGV (Central University), Bilaspur, Chhattisgarh - 495 009, India. ${ }^{6}$ Department of Chemistry, Faculty of Science, Umm Al-Qura, University, Makkah, Saudi Arabia.
\end{abstract}

\begin{abstract}
Natural products are an excellent source of therapeutic products which has led to the discovery of many important drugs that play an important role in the treatment of various human diseases. In this current study two compounds has been isolated from Senecio royleanus DC. (Asteraceae) were undertaken for antibacterial and antifungal activity against five bacterial and fungal pathogens. The compounds isolated from Senecio royleanus, viz; 1,10 $\beta$-epoxy 6-oxo-furanoeremophilan and $1 \beta$, 10-epoxy-furanoeremophilan displayed a very important role against all bacterial and fungal strains. 1,10 $\beta$-epoxy 6-oxo-furanoeremophilan showed maximum antibacterial activity against Agrobacterium tumefaciens $(13 \mathrm{~mm})$. While it showed maximum fungal activity against Fusarium oxysporum (15 $\mathrm{mm}) .1 \beta, 10$-Epoxy-furanoeremophilan was found inactive in antibacterial activity against Escherichia coli, and showed maximum zone of inhibition against bacterial strain of Bacillus subtilis (12 $\mathrm{mm})$. It showed $12 \mathrm{~mm}$ zone against Rhizoctonia solani during antifungal activity. The fractions which showed significant antimicrobial activity i.e. (zoi $\geq 10 \mathrm{~mm}$ ), were further tested to find out minimuminhibitory concentration and minimum bactericidal concentration at different concentrations.
\end{abstract}

Keywords: Asteraceae/aenecio, royleanus, Antifungal activity, Antibacterial activity.

*Correspondence: shakeeliqubal@gmail.com; +919891308291; +966570158198

(Received: 29 July 2019; accepted: 06 September 2019)

Citation: Chandra Mohan Singh Bisht, S.M. Shakeel Iqubal' Aejaz A. Khan, Tasneem Mohammed, Areej Dawoud, Mohammed Gamal, S.K. Singh and Basim H. Asghar, Natural Products in Drug Discovery: Antibacterial and Antifungal Activity of Essential Oil of Compound Isolated from Senecio royleanus, J Pure App/ Microbiol., 2019; 13(3): 1611-1617. https://doi.org/10.22207/JPAM.13.3.34

C The Author(s) 2019. Open Access. This article is distributed under the terms of the Creative Commons Attribution 4.0 International License which permits unrestricted use, sharing, distribution, and reproduction in any medium, provided you give appropriate credit to the original author(s) and the source, provide a link to the Creative Commons license, and indicate if changes were made. 


\section{INTRODUCTION}

Senecio belongs to family Asteraceae which is predominantly grown in central Himalayan region. Senecio royleanus DC grows in hilly slopes and moist localities above $2,400 \mathrm{~m}$. Its flowering and fruiting occurs from the month of July to October. Bohlmann et al., 1977, ${ }^{1}$ have reported and investigated more than sixty species of Senecio in an attempt to discover new natural products. Derivative of shikimic acid, eremophilane, germacrene and bisabolane are the main constituents which have been investigated from Chilean, Portugese, Maxican and some Himalayan Senecio species (Bohlmann et al., 1977; Cardoso, Jakupovic, Bohlmann, 1987; Dupre et al., 1991; Bohlmann, Zdero, 1974; Bohlmann, Zdero, 1976). ${ }^{1,2,3,4,5}$ Further literature reports confirmed the presence of essential oils like 1-undecene, 1-tridecene, Germacrene D, $\alpha$-copaene, $\beta$-caryophyllene, myrcene and anhydrooplonone have been reported to be principal constituents from Senecio congestus, S. jacobaea, S. vulgaris and S. fuchsia (Dooren, Bos, Tattje, 1981). ${ }^{6}$ All the parts of plant have essential oil constituents. $\alpha$-pinene is the major composition in the leaf oil of S. quinqueobus (Chaturvedi, Saxena, 1982), ${ }^{7}$ p-cymene (29.3\%) and $\alpha$-phellandrene (24.7\%) (Chalchat et al., 2004), ${ }^{8}$ have been found in aerial parts of the species growing in Serbia ( $S$. squaledus). The essential oil of $S$. farfarifolius constituents $\alpha$-pinene $(48.3 \%)$ and 1,8 -cineole (10.3\%) which have been isolated from the aerial part and is cultivated in Turkey (Baser, Demirci, 2004). ${ }^{9}$

S. amplexicaulis and S. alatus growing widely in Himalayan region were investigated and were found that it possess two new furanoeremophilanes, four eremophilanolides and a novel derivative of hydroxyeremophilane (Bohlmann, Ziesche, 1980). ${ }^{10}$ In an another study, six new highly oxygenated germacrene derivatives were isolated from S. galpinii, while S. coronatus afforded two new cacalol derivatives (Bohlmann, Zdero, 1982). ${ }^{11}$

It has been reported that $S$. arnicoides collected from Pindari glacier of Kumaon Himalaya is a highly toxic herb, the ethanolic extract of the roots of this plant were extracted using ethanol and the extract was found to be a constituent moisture of four furanoeremophilane epoxide esters, $\beta$-sitosterol and stigmasterol (Khetwal, Manral, 1987) ${ }^{12}$ S. linifolius was subjected to extraction using acetone and the chloform fraction of this extract shows presence of maturinone, four new furanoeremophilanes and angelic acid (Torres et al., 1989) ${ }^{13}$. The aerial parts of S. aegyptius var. discoideus was subjected to distillation using dichloromethane. Its dichloromethane extract was nine eremophilane compounds out of which six were novel and not been reported. These isolated products were tested for antibacterial activity against Bacillus cereus and a Serratia $S p$ (Mohamed, Ahemed, 2005). ${ }^{14}$

In our current study we reported the antimicrobial activity of isolated compounds $(1 \beta, 10$-epoxy-furanoeremophilan and 1,10 $\beta$ activityepoxy-6-oxo-furanoeremophilan) from $S$. royleanus against certain pathogens.

\section{MATERIAL AND METHODS Sample Collection}

Senecio royleanus DC. was collected from Rambara, a small station on the way to Kedarnath (India) in the first week of October in its flowering stage. The essential oil was obtained from whole aerial parts ( $1 \mathrm{ft}$. to $1 \mathrm{~m}$ tall).

Isolation of Major Compounds from Essential Oil

The essential oil was obtained by steam distillation using copper still fitted with spiral glass condensers. The aqueous distillate was saturated with $\mathrm{NaCl}$ and the oil was extracted with hexane. The hexane extract was dried over anhydrous $\mathrm{Na}_{2} \mathrm{SO}_{4}$. The solvent was removed using a rotovap at aspirator pressure and temperature at $25^{\circ} \mathrm{C}$ to yield $1.8 \mathrm{~g}(0.18 \%)$ of the oil. The isolation and identification of major constituent was done by the help of chromatographic (TLC, Column chromatography, GC, GC-MS) and spectroscopic techniques (IR, ${ }^{1} \mathrm{H}-\mathrm{NMR}$, ${ }^{13}$ C NMR, DEPT, COSY, HETCORE ). The isolated major constituents identified as SR-I ( $1 \beta$, 10-epoxyfuranoeremophilan) and SR-II (1, 10 $\beta$-epoxy-6-oxo-furanoeremophilan). ${ }^{15}$

\section{Antimicrobial Assay}

For the evaluation of broad spectrum antimicrobial activity both isolated compounds i.e. $1 \beta, 10$-epoxy-furanoeremophilan and 1,10 $\beta$-epoxy6-oxo-furanoeremophilan from Senecio royleanus were tested against five pathogenic bacterial strains (gram positive animal pathogenic-Bacillus subtilis- 


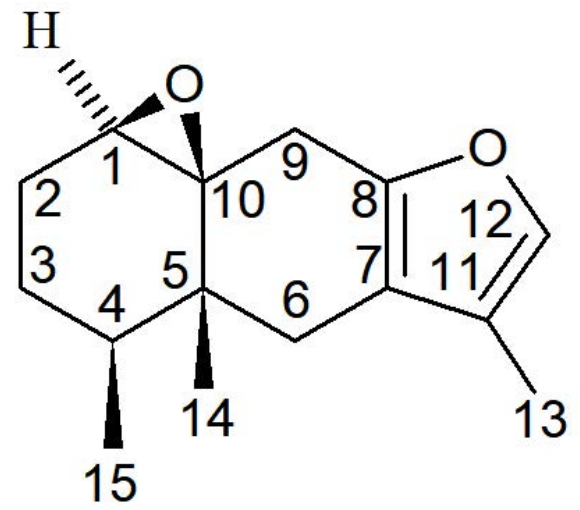

$1 \beta$, 10-epoxyfuranoeremophilan

MTCC 121, and gram negative Agrobacterium tumefaciens (MTCC 609), Erwinia chrysanthmiKUMSCC 328, Xanthomonas phaseoli- KUMSCC 327 and Escherichia coli- MTCC 40) and five plant pathogenic fungal strains (Pyricularia oryzaeKUMSCC 621, Fusarium oxysporum- MTCC 350, Rhizoctonia solani- MTCC 4633, Sclerotium rolfsii- KUMSCC 629 and Sclerotinia sclerotiorumKUMSCC 635). All the bacteria and fungi used in this study are known to cause various diseases in plants and animals. The pathogens were acquired from Institute of Microbial Technology, Chandigarh i.e. MTCC: Microbial Type Culture Collection and Aquatic Myco-Pathology Research Laboratory, KUMSCC: Kumaun University Mycological Slide Culture Collection.

\section{Determination of Antimicrobial Activity}

The preparatory screening of antibacterial and antifungal activity was conducted at $1000 \mu \mathrm{g} /$ $\mathrm{mL}$ concentration. Antibacterial and antifungal activity of isolated compounds were tested by using disc-diffusion method, Streptomycin $(50 \mathrm{mg} /$ $\mathrm{mL}$ ) was used as positive control for antibacterial activity and Clotrimazole $(50 \mathrm{mg} / \mathrm{mL})$ was used as positive control in case of antifungal evaluation. In the antibacterial and antifungal analysis, all the fractions which showed significant antimicrobial activity (zone of inhibition $\geq 10 \mathrm{~mm}$ ), were further tested to find out MIC and MBC.

\section{Test for Antibacterial Activity}

The antibacterial activity was employing the disc-diffusion method (Bauer et al., 1966). ${ }^{16}$ In the analysis of antibacterial activity nutrient agar media having $\mathrm{pH}$ value $7.3 \pm 0.2$ was used, which

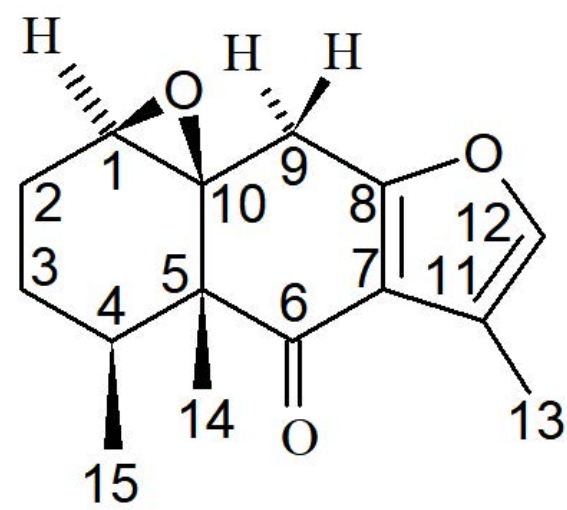

1, 10 ß-epoxy-6-oxo-furanoeremophilan

was autoclaved at $121^{\circ} \mathrm{C}$ for 30 minutes at $15 \mathrm{lb}$ pressure. Whatman filter paper no. 1 was used to prepare discs with $5 \mathrm{~mm}$ diameter and placed in previously sterilized petridishes. After sterilization of nutrient media, and cooling down to $50^{\circ} \mathrm{C}, 20 \mathrm{~mL}$ of molten media was added into petridishes in the laminar room. Inoculation of the microorganisms was done in laminar room. Microorganisms were streaked on the media of petridishes with the help of glass rod with cotton swab over the flame, this method was repeated by streaking two more times, rotating the plate at $60^{\circ}$. After inoculation, plates were dried at room temperature for half an hour.

Once plates were inoculated with the microorganism, three filter discs of $5 \mathrm{~mm}$ diameter, one containing isolated compound from essential oil, another one of used solvent (negative control, $\mathrm{n}$-hexane) and one disc of standard antibiotics (positive control) was applied in clockwise pattern with the help of forceps. Forceps was gently flamed before and after each disc application and cover the petriplates with parafilm. Each set of experiment was done in triplicate, plates were inverted and placed in an incubator $\left(37^{\circ} \mathrm{C} \pm 1^{\circ} \mathrm{C}\right)$.

After 24 hours of incubation each plate was examined for growth and inhibition. The diameter of complete inhibition zone (as judged by unaided eyes) was measured, including the diameter of the disc. Zones were measured to the nearest whole millimetre, using a ruler. The inhibition zone margin was taken as the area showing no obvious, visible growth that can be detected with the unaided eyes. Faint growth 
of tiny colonies which cannot be detected with unaided eyes or resistant colonies due to bacteristatic property of tested oils or compounds were ignored.

Determination MIC (minimum inhibitory concentration) and MBC (minimum bactericidal concentration

The samples showing zone of inhibition $\geq 10 \mathrm{~mm}$ were further tested for the minimum inhibitory concentration (MIC) and minimum bactericidal concentration (MBC) to determine the minimum concentration of the oil or compound that inhibits the visible growth of test microorganisms or kill the microorganisms. This test was performed at different concentrations of the oil and compound (31.25, 62.5, 125.0, 250.0 and $500.0 \mu \mathrm{g} / \mathrm{mL}$ ) using disc-diffusion technique. In the analysis of MIC/MBC same media and paper disc were used as described earlier.

Once plates were inoculated with the microorganism, five filter paper discs of $5 \mathrm{~mm}$ diameter, containing five different concentrations of plant oils and isolated compounds solutions were applied in clockwise pattern. Each disc was picked up with sterile flamed forceps and placed into the agar plate. After each disc application forceps was gently flamed and petriplates were sealed with parafilm. Each set of experiment was done in triplicate. The plates were kept for incubation at $37^{\circ} \mathrm{C} \pm 1^{\circ} \mathrm{C}$ for overnight.

MIC

The minimum concentration of compound, which inhibited the visible bacterial growth of test microorganisms within zone of inhibition, was recorded as MIC.

MBC

The same test was used to determine the minimum bactericidal concentration. For evaluation of concentration as bactericidal, the petridishes not showing any visible growth in the MIC test were sub-cultured and incubated at $37^{\circ} \mathrm{C}$ $\pm 1^{\circ} \mathrm{C}$ overnight. The highest dilution showing at least $99 \%$ inhibition was recorded as MBC.

\section{Test for Antifungal Activity}

The fungi toxic activity of isolated compounds from Senecio royleanus was tested against five plant pathogenic fungal strains employing the disc-diffusion method (Bauer et al., 1966) ${ }^{16}$. In the analysis of antifungal activity, malt extract agar media having $\mathrm{pH}$ value $6.0 \pm$
0.2 was used and autoclaved at $121^{\circ} \mathrm{C}$ for 30 minutes at $15 \mathrm{lb}$ pressure. After sterilization of malt extract agar media, and cooling down to $50^{\circ} \mathrm{C}, 20 \mathrm{~mL}$ of molten media was added into previously sterilized petridishes in the laminar room. To determine antifungal activity of isolated compounds disc-diffusion method was used. In this method, two filter discs of $5 \mathrm{~mm}$ diameter, one containing isolated compound and another disc of standard antibiotics were applied one prepared petridishes. Each disc was applied in a horizontal line equal distance from the centre with sterile flamed forceps. Forceps were gently flamed after each disc application. Disc of test fungi ( 5 $\mathrm{mm}$ diameter), cut with the help of sterilized cork borer from the periphery of a seven days old culture was inoculated aseptically to the centre of each petriplate in between treatment and control sets, in both, Agar-well as well as Discdiffusion method and petriplates were sealed with parafilm. The petriplates were incubated at $27^{\circ} \mathrm{C}$ $\pm 1^{\circ} \mathrm{C}$ for one week in incubation chamber. After 7 days of incubation, each plate was examined for the inhibition zone and the area was measured including the diameter of the well. The diameter of complete inhibition zone is double of the distance between the circumference of fungal colony from the centre of well in both treatment as well as control cases (as judged by the unaided eyes). The distance between the circumference of fungal colony from the centre of well in both cases were measured to the nearest whole millimetre, using a ruler. Faint growth of tiny colonies which cannot be detected with unaided eyes was ignored.

\section{RESULTS AND DISCUSSION}

The chemical compounds like furanoeremophilans were isolated from Senecio royleanus DC. (Asteraceae) plant. The isolated was characterized by various techniques like infra red spectroscopy showed various functional groups in the extract and NMR techniques to confirm the new compounds based on the carbon number. These new compound were employed for its antibacterial and antifungal activity against various pathogens.

The furanoeremophilans were found active against almost all the bacterial strains. 1,10 $\beta$-epoxy 6-oxo-furanoeremophilan isolated from $S$. royleanus was found active against all 
bacterial strains. It showed maximum zone of inhibition ( $13 \mathrm{~mm}$ ) against $A$. tumefaciens followed by $B$. subtilis $(11 \mathrm{~mm})$. Against E. chrysanthemi and $X$. phaseoli the zone of inhibition was observed $09 \mathrm{~mm}$. Lowest zone of inhibition

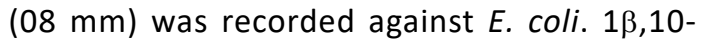
epoxy furanoeremophilan (S. royleanus) showed maximum activity against $B$. subtilis $(12 \mathrm{~mm})$

Table 1. Antibacterial screening of isolated compounds

\begin{tabular}{|c|c|c|c|}
\hline \multirow[t]{2}{*}{$\begin{array}{l}\text { Microorganism } \\
\text { (Bacteria) }\end{array}$} & \multicolumn{3}{|c|}{$\begin{array}{l}\text { Zone of Inhibition (mm) } \\
\text { Isolated compounds }\end{array}$} \\
\hline & SR-I & SR- II & Str. \\
\hline A. tumefaciens & 11 & 13 & $18 E$. \\
\hline chrysanthemi & 08 & 09 & 18 \\
\hline X. phaseoli & 08 & 09 & 19 \\
\hline E. coli & $*$ & 08 & 17 \\
\hline B. subtilis & 12 & 11 & 17 \\
\hline
\end{tabular}

SR-I: $1 \beta, 10-e p o x y$ furanoeremophilan;

SR-II: 1, 10 $\beta$-epoxy-6-oxo furanoeremophilan;

*: Inactive and Str.: Streptomycin $(50.0 \mu \mathrm{g} / \mathrm{mL})$.

Table 2. The MIC/MBC data of isolated compounds

\begin{tabular}{lcccccc}
\hline Isolated & Microorganism & \multicolumn{5}{c}{ Concentration $(\mu \mathrm{g} / \mathrm{mL})$} \\
\cline { 3 - 6 } compound & (Bacteria) & 500.0 & 250.0 & 125.0 & 62.5 & 31.25 \\
\hline SR-I & A.tumefaciens & 08 & 08 & $07+$ & $\mathrm{R}$ & $\mathrm{R}$ \\
$\mathrm{SR}-\mathrm{I}$ & B. subtilis & 09 & $08^{-}$ & $\mathrm{R}$ & $\mathrm{R}$ & $\mathrm{R}$ \\
$\mathrm{SR}-\mathrm{II}$ & A.tumefaciens & 11 & 09 & $07^{-}$ & $\mathrm{R}$ & $\mathrm{R}$ \\
$\mathrm{SR}-\mathrm{II}$ & B. subtilis & 09 & $07+$ & $\mathrm{R}$ & $\mathrm{R}$ & $\mathrm{R}$ \\
\hline
\end{tabular}

SR-I: 1及,10-epoxy furanoeremophilan; SR-II: 1, 10ß-epoxy-6-oxo furanoeremophilan;

$\triangle$ : Minimum inhibitory concentration (MIC); *: Minimum bactericidal concentration (MBC);

+: MIC values coincide with MBC and R: Resistant.

Table 3. Antifungal screening of isolated compounds

\begin{tabular}{|c|c|c|c|}
\hline \multirow[t]{2}{*}{$\begin{array}{l}\text { Microorganism } \\
\text { (Fungi) }\end{array}$} & \multicolumn{3}{|c|}{$\begin{array}{l}\text { Zone of Inhibition ( } \mathrm{mm} \text { ) } \\
\text { Isolate dcompounds }\end{array}$} \\
\hline & SR-I & SR- II & Clt. \\
\hline P. oryzae & 09 & 09 & 10 \\
\hline F. oxysporum & 11 & 15 & 11 \\
\hline R.solani & 12 & 09 & 12 \\
\hline S. rolfsii & 08 & 12 & 10 \\
\hline S. sclerotiorum & 07 & 08 & 14 \\
\hline
\end{tabular}

SR-I: $1 \beta, 10$-epoxy furanoeremophilan; SR-II: 1, 10ß-epoxy 6-oxo furanoeremophilan; and Clt.: Clotrimazole $(50 \mathrm{mg} / \mathrm{mL})$. followed by $A$. tumefaciens $(11 \mathrm{~mm}$ ) but no inhibition zone was observed against $E$. coli. In case of $E$. chrysanthemi and $X$. phaseoli, the zone of inhibition recorded was $08 \mathrm{~mm}$, Table 1.

For MIC and MBC, only those bacterial strains were taken up against which, oil samples and compounds showed significant inhibition ( $\geq 10 \mathrm{~mm}$ ) at $1000 \mu \mathrm{g} / \mathrm{mL}$. The MIC and MBC analysis was performed at different concentrations of the oils and compounds solutions (31.25, $62.5,125.0,250.0$ and $500.0 \mu \mathrm{g} / \mathrm{mL}$ ) using discdiffusion technique. Each set of experiment was done in triplicate Table 2, (1, 10ß-epoxy 6-oxoagainst $A$. tumefaciens at $125 \mu \mathrm{g} / \mathrm{mL}$, while against $B$. subtilis the inhibitory value coincide with cidal value at $125 \mu \mathrm{g} / \mathrm{mL}$. For $1 \beta, 10$-epoxyfuranoeremophilan the MIC was $125 \mu \mathrm{g} / \mathrm{mL}$ which coincide with cidal value against $A$. Tumefaciens but it showed inhibitory effect against $B$. subtilis at $250 \mu \mathrm{g} / \mathrm{mL}$. furanoeremophilan) exhibited inhibitory effect
It is very interesting to note that the oil and compounds isolated from Senecio royleanus enhances the growth of $S$. rolfsii, tremendously. It indicated that the oil and compounds isolated from Senecio royleanus might perhaps act as growth promoter for S. rolfsii. 1,10 $\beta$-epoxy 6-oxo furanoeremophilan (S. royleanus) showed maximum activity against $F$. oxysporum $(15 \mathrm{~mm})$ followed by $S$. rolfsii $(12 \mathrm{~mm})$. Whereas inhibition zone against $P$. oryzae and $R$. solani was found 09 $\mathrm{mm} .1 \beta, 10$-epoxy furanoeremophilan gave zone of inhibition $12 \mathrm{~mm}$ against $R$. solani followed by F. oxysporum $(11 \mathrm{~mm})$, P. oryzae $(09 \mathrm{~mm})$ and $S$. rolfsii $(08 \mathrm{~mm})$ Table 3.

and Clt: Clotrimazole $(50 \mathrm{mg} / \mathrm{mL}$. 
In Table 4, for the determination of MIC, only those fungal strains were taken up against which, isolated compounds showed significant inhibition ( $\geq 10 \mathrm{~mm}$ ) at $1000 \mu \mathrm{g} / \mathrm{mL}$. It was performed at different concentrations $(31.25,62.5$,
$125.0,250.0$ and $500.0 \mu \mathrm{g} / \mathrm{mL}$ ) using disc-diffusion technique.

The furanoeremophilans (Senecio royleanus) showed significant antifungal activity against tested strains. $1,10 \beta$-epoxy 6 -oxo-

Table 4. The MIC data of different isolated compounds

\begin{tabular}{lcccccc}
\hline \multirow{2}{*}{$\begin{array}{l}\text { Isolated } \\
\text { compound }\end{array}$} & $\begin{array}{c}\text { Microorganism } \\
\text { (Fungi) }\end{array}$ & \multicolumn{5}{c}{ Concentration $(\mu \mathrm{g} / \mathrm{mL})$} \\
\cline { 3 - 7 } & & 500.0 & 250.0 & 125.0 & 62.5 & 31.25 \\
\hline SR-I & F. oxysporum & 09 & $07 \mathrm{t}$ & $\mathrm{R}$ & $\mathrm{R}$ & $\mathrm{R}$ \\
SR-I & R. solani & 11 & 09 & $07 \mathrm{t}$ & $\mathrm{R}$ & $\mathrm{R}$ \\
SR-II & F. oxysporum & 12 & 11 & 09 & $07 \mathrm{t}$ & $\mathrm{R}$ \\
SR-II & S. rolfsii & 10 & 09 & $08 \mathrm{t}$ & $\mathrm{R}$ & $\mathrm{R}$ \\
\hline
\end{tabular}

furanoeremophilan had inhibitory effect against F. oxysporum at $62.5 \mu \mathrm{g} / \mathrm{mL}$, while against S. rolfsii, the inhibitory value was observed to be $125 \mu \mathrm{g} /$ $\mathrm{mL}$. Similarly, 1 13 , 10-epoxy-furanoeremophilan exhibited inhibitory effect against F.solani and R.solani at 250 and $125 \mu \mathrm{g} / \mathrm{mL}$, respectively.

\section{CONCLUSION}

The present investigation revealed that in both analysis antibacterial and antifungal activities observed. The results also suggest that these plant oils have broad spectrum antimicrobial activity to treat fungal and bacterial ailments against many pathogens found in variety of crops. It is first report on the antimicrobial analysis of the compounds isolated from Senecio royleanus against the selected pathogens.

\section{ACKNOWLEDGEMENTS}

The authors are thankful to Mr. Mayank Agarawal (M.D. IIMT Group of Colleges, Greater Noida (Delhi NCR, U.P., India) for giving us constant encouragement, support and blessings. we express our thanks to Mr. Umesh Kumar (Director IIMT College of Polytechnic, Greater Noida, Delhi NCR, U.P., India) who always motivating and inspiring us. CMS is thankful to V. Dev and P.S. Beauchamp Department of Chemistry, California State Polytechnic, University, Pomona, USA for their valuable support during spectroscopic work. I am highly indebted to Prof. A. B. Melkani and Prof. S. C. Sati Kumaun University, Nainital for their continuous guidance through the work and generous help in the determination of antimicrobial activity.

\section{CONFLICT OF INTEREST}

The authors declares that there is no conflict of interest.

\section{AUTHORS' CONTRIBUTION}

All authors have made substantial contribution to the work and approved it for publication.

\section{FUNDING}

None.

\section{DATA AVAILABILITY}

All datasets generated or analyzed during this study are included in the manuscript.

\section{REFERENCES}

1. Bohlmann F, Knell KH, Zdero C, Mahanta P K, Grenz M, Suwita A, Ehlers D, Le Van, Abraham WR, Natu AA. Terpen- derivate aus Senecio-arten. Phytochemistry, 1977; 16: 965-985. https://doi.org/10.1016/S00319422(00)86705-9

2. Cardoso JM, Jakupovic J, Bohlmann F. Eremophilane-, bisabolane- and shikimic acid-derivatives from Portugese Senecio species. Phytochemistry, 1987; 26: 2321-2324. https://doi.org/10.1016/S00319422(00)84711-1

3. Dupre S, Grenz M, Jakupovic J, Bohlmann F, Niemeyer HM. Eremophilane, germacrane and shikimic acid derivatives from chilean Senecio species. Phytochemistry, 1991; 30: 1211-1220. https://doi. org/10.1016/S0031-9422(00)95204-X

4. Bohlmann F, Zdero C. Naturally Occuring Terpene 
Derivatives, XLI. On New Sesquiterpenes from the Genus Senecio. Chem. Ber., 1974; 107: 2912-2922. https://doi.org/10.1002/cber.19741070913

5. Bohlmann F, Zdero C. Naturally Occurring Terpene Derivatives, LVII. Further Furanoeremophilanes from Othonna Species. Chem. Ber., 1976; 109: 1230-1238. https://doi.org/10.1002/cber.19761090403

6. Dooren BV, Bos R, Tattje DHE. Composition of essential oils of some Senecio species. Planta Med., 1981;42:385389. https://doi.org/10.1055/s-2007-971660

7. Chaturvedi SK, Saxena VK. Volatile constituents of leaves of Senecio quinquelobus. Indian Perfum., 1982; 26: 138-139.

8. Chalchat JC, Maksimivic ZA, Petrovic SD, Gorunovic MS. Essential Oil of Senecio squalidus. J. Essent. Oil Res., 2004; 16: 227-228. https://doi.org/10.1080/10 412905.2004.9698704

9. Baser KHC, Demirci B. The essential oil of Senecio farfarifolius Boiss. et Kotschy growing in Turkey. J. Essent. Oil Res., 2004; 16: 558-559. https://doi.org/1 $0.1080 / 10412905.2004 .9698797$

10. Bohlmann F, Ziesche J. Eremophilane derivatives from Senecio species. Phytochemistry, 1980; 19: 2681-2684. https://doi.org/10.1016/S0031-9422(00)83943-6

11. Bohlmann F, Zdero C. Germacrene derivatives and other sesquiterpenes from Senecio species and Lordhowea insularis. Phytochemistry, 1982; 21: 25372541. https://doi.org/10.1016/0031-9422(82)85252-7

12. Khetwal KS, Manral K. Constituents of High Altitude Himalayan Herbs; Part I. Furanoeremophilanes from Senecio arnicoides. Planta. Med., 1987; 54: 188189. https://doi.org/10.1055/s-2006-962397

13. Torres $P$, Chinchilla R, Asensi MC, Grande $M$. Furanoeremophilane derivatives from Senecio flavus. Phytochemistry, 1989; 28: 3093-3095. https://doi. org/10.1016/0031-9422(89)80286-9

14. Mohamed AEHH, Ahemed AA. Eremophilane-Type Sesquiterpene Derivatives fro Senecio a egyptius var. discoideus. J. Nat. Prod., 2005; 68: 439-442. https:// doi.org/10.1021/np049732I

15. Bisht CMS, Melkani AB, Dev V, Beauchamp PS. 1,10 $\beta$-Epoxy-6- oxofuranoeremophilane and other terpenoids from the essential oil of Senecio royleanus DC. J. Essent. Oil Res., 2011; 23: 102-104. https://doi. org/10.1080/10412905.2011.9700434

16. Bauer AW, Kirby WMM, Sherris JC, Turck M. Antibiotic susceptibility testing by a standardized single disk method. Am. J. Clin. Pathol. 1966; 45: 493-496. https:// doi.org/10.1093/ajcp/45.4_ts.493 